\title{
Original
}

\section{Effect of Acids on Teeth and Restorative Materials: An Aid in Forensic Odontology}

\author{
Thanuja Seethapathy $^{1)}$, Sanjeevareddygari Shylaja ${ }^{1)}$, Manay Srinivas Muni Sekhar ${ }^{2)}$, Suvarna Manthapuri $^{1)}$, \\ Oruganti Venkata Ramanand $^{1)}$, Sharath Kumar Reddy ${ }^{1)}$, Juliana Beryl Paul ${ }^{1)}$, Akiyoshi Funato ${ }^{3)}$, Katsutoshi Kubo ${ }^{3)}$, Hatsuhiko Maeda ${ }^{3)}$ \\ and Mohammad Khursheed Alam ${ }^{2}$
}

\author{
${ }^{1)}$ Department of Oral and Maxillofacial Pathology, SVS Institute of Dental Sciences, Mahabubnagar, Telangana, India \\ ${ }^{2)}$ Department of Preventive Dentistry, College of Dentistry, Jouf University, Sakaka, Kingdom of Saudi Arabia \\ ${ }^{3)}$ Department of Oral Pathology, School of Dentistry, Aichi Gakuin University, Nagoya, Japan \\ (Accepted for publication, October 30, 2018)
}

\begin{abstract}
The nature of crime is changing day by day and the forensic scientists are always facing new problems in human identification. The practice of destroying human body by immersing in an acid is drawing a great deal of forensic interest these days. The present study aimed to identify the acid that is most likely used in such crimes and to determine if the morphological changes in teeth and different restorative materials could predict the approximate duration of time elapsed after immersion of a body in an acid. 240 teeth with and without different restorations were immersed separately in 3 different acids and were observed for morphological changes over a period of 30 days. Teeth dissolved completely in hydrochloric acid $(\mathrm{HCl})$ and nitric acid $\left(\mathrm{HNO}_{3}\right)$ by $48 \mathrm{hrs}$ and $20 \mathrm{hrs}$ respectively. Teeth showed precipitation in sulphuric acid $\left(\mathrm{H}_{2} \mathrm{SO}_{4}\right)$ with only remnants of white precipitate by the end of $288 \mathrm{hrs}$. Amalgam restorations in $\mathrm{HCl}$ did not show any changes. They exhibited blackish discoloration on the surface when placed in $\mathrm{H}_{2} \mathrm{SO}_{4}$, but in $\mathrm{HNO}_{3}$, they settled as silver powder with the release of brown fumes. Composite restorations in $\mathrm{HCl}$ and $\mathrm{HNO}_{3}$ did not demonstrate considerable morphological changes. $\mathrm{In}_{2} \mathrm{SO}_{4}$, they showed surface discoloration and softening. Glass ionomer cement (GIC) in $\mathrm{HCl}$ and $\mathrm{HNO}_{3}$ dissolved completely. $\mathrm{In}_{2} \mathrm{SO}_{4}$ they settled as white precipitate. When a human body is destroyed using acids, teeth or restorative materials retrieved can serve as an effective tool in crime investigations and can help the investigator to deduce the time elapsed since the commitment of crime.
\end{abstract}

Key words: Acids, Teeth, Restorations, Investigations, Crime.

\section{Introduction}

Human identification is one of the most challenging subjects that man has been confronted with. Forensic odontology has established itself as an important and often indispensable science in medico-legal matters and in particular in identification of the dead ${ }^{1-3)}$. The importance of dental identification is on the rise year after year. With the passage of time, the role of forensic odontology has increased, as very often teeth and dental restorations are the only means of identification ${ }^{2}$.

Teeth are considered to be essential organs in both living and nonliving population for anthropological, genetic, odontologic and forensic investigations. This is due to the hardness and high resistance of dental tissues to degradation and putrefaction which enable the teeth to survive for longer periods than other human tissues ${ }^{4}$, making them more resistant to trauma, decomposition, water immersion, chemicals and fire, serving as an invaluable evidential source. To match these natural requirements, the foreign materials subsequently placed in the mouth by the dental practitioner such as fillings, dentures, crowns, bridges and implants must be equally resistant to the intense mechanical demands placed upon them and therefore their survivability ${ }^{5}$.

As we enter a new millennium, society is faced with fresh challenges in every conceivable area. Despite leaps in modern technology, medical breakthroughs and the geographical changes that the last century has

Correspondence to: Dr. Manay Srinivas Muni Sekhar, Department of Oral Pathology, College of Dentistry, Jouf University, Sakaka, 42421 Kingdom of Saudi Arabia; Tel: +966502899178; Email: drmunisekhar@gmail.com brought, crime still persist in all aspects of our lives ${ }^{6}$. The seeds of modern forensic science were sown in the last quarter of the nineteenth century. Progress from that time has been slow but steady ${ }^{7}$.

Moreover, the nature of crime is changing day by day and the forensic scientists are always facing new problems in the process of identification. The practice of destroying the human body by immersing in an acid is drawing a great deal of forensic interest these days. Crimes of this nature have been frequently reported in Italy ${ }^{1,8}$. The forensic scientist needs to know whether it is possible to destroy the human body partially or totally by immersing it in an acid and, if so, how much time is necessary for its complete destruction. Another important question that arises in this context is whether there are any means of identifying the deceased individual from the residual remains").

John George Haigh, commonly known as the Acid Bath Murderer, was an English serial killer in the 1940s. In the Acid Bath murders committed by John George Haigh at Crawley, Sussex in 1949, it was the dentures that proved the identity of one of his victims. What Haigh did not know was that, the acrylic dentures dissolve very slowly in concentrated sulphuric acid $\left(\mathrm{H}_{2} \mathrm{SO}_{4}\right)^{10-12)}$.

Following a literature review, there have not been many studies performed in the past using teeth as an aid in identifying a person, when they were immersed in an acid. No positive identifications related to events of acid dissolution were reported. Keeping this in mind, the present study was carried out to see if the morphological changes on the teeth as well as restorative materials when placed in contact with differ- 


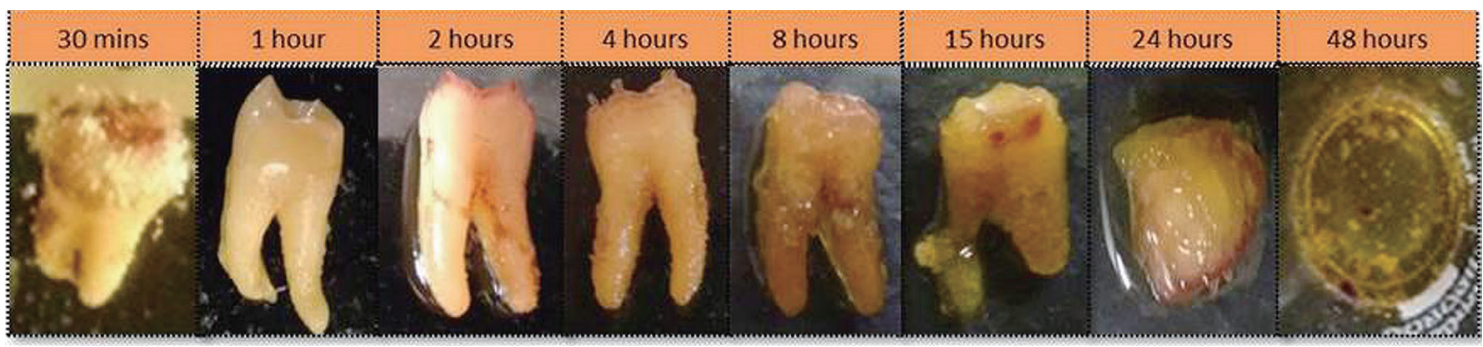

Figure 1. Sequential morphological changes observed in teeth after immersion in hydrochloric acid

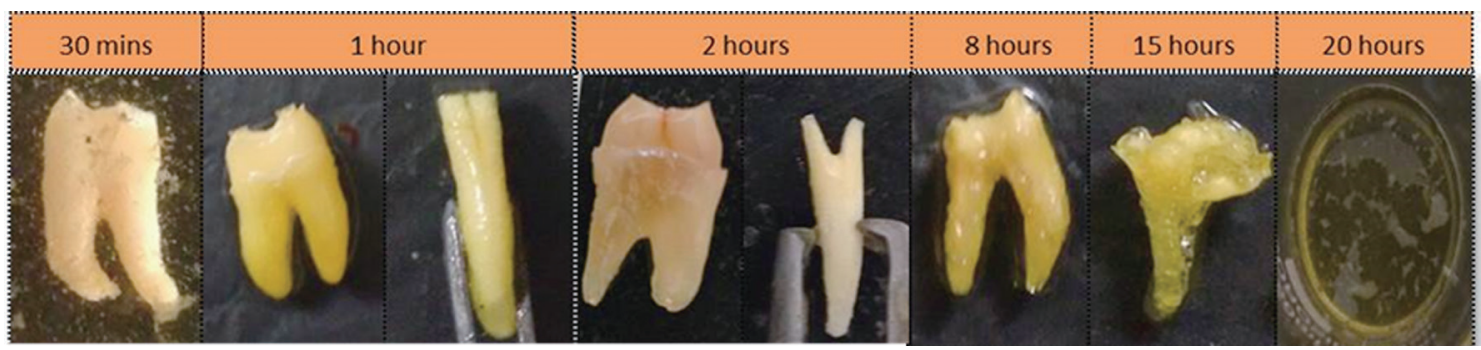

Figure 2. Sequential morphological changes observed in teeth after immersion in nitric acid

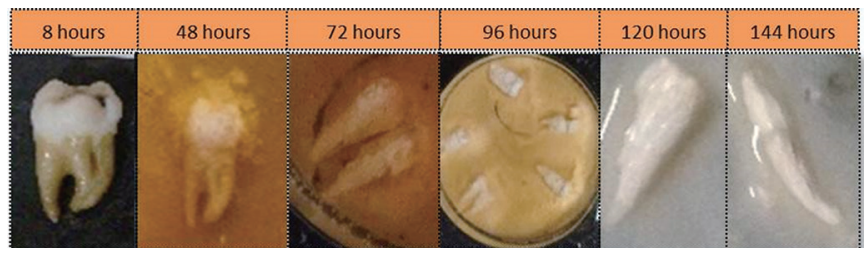

Figure 3. Sequential morphological changes observed in teeth after immersion in sulphuric acid

ent acids are of any help in identifying the acid used in such crimes and also to deduce the time elapsed from committing the crime.

The aims of the study are, to identify the agent (acid) that is most likely used in the crimes, where acids are employed to mask the human identification and to analyze the morphological changes in the teeth and different restorative materials namely Amalgam, Glass Ionomer Cement (GIC) and Composites, induced by acids such as Hydrochloric acid $(\mathrm{HCl})$, Nitric acid $\left(\mathrm{HNO}_{3}\right)$ and Sulphuric acid $\left(\mathrm{H}_{2} \mathrm{SO}_{4}\right)$ at various time intervals of 30 mins, 1 hr., 2 hrs., 4 hrs., 8 hrs., 15 hrs., 20 hrs., 24 hrs., and subsequently for every $24 \mathrm{hrs}$ until 30 days. As well as, to determine, if the morphological changes in the teeth and restorative materials could be used to predict the approximate duration of time elapsed after immersion of a body in an acid.

\section{Materials and Methods}

240 extracted human natural teeth used for the study were obtained as per the protocol approved by the institutional ethics committee of SVS Institute of Dental Sciences, Mahabubnagar.

Inclusion Criteria: Teeth extracted for orthodontic purposes (Therapeutic extractions) and impacted teeth free of any defects.

Exclusion Criteria: Teeth with carious defect, teeth with pulpal, periapical or periodontal diseases, teeth with attrition, abrasion, and erosion or any developmental anomalies, and fractured teeth were excluded from the study.

The following acids were used in the study

- $37 \%$ Hydrochloric acid ( $\mathrm{HCl}$ )-Finar Chemicals, Pune, India.

- $65 \%$ Nitric acid $\left(\mathrm{HNO}_{3}\right)$ - SDFCL, Mumbai, India.

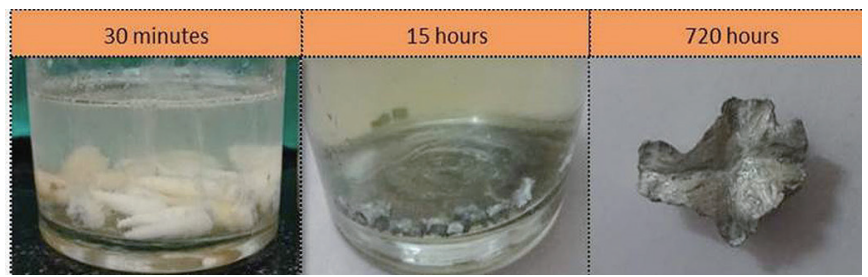

Figure 4. Sequential morphological changes observed in amalgam after immersion in hydrochloric acid

- $96 \%$ Sulphuric acid $\left(\mathrm{H}_{2} \mathrm{SO}_{4}\right)$ - Merck Specialities Private Limited, Mumbai, India.

The different restorative materials used in the study were

\section{Amalgam}

Silver powder- Dental products of India a division of The Bombay Burmah Trading Corporation Ltd. Mumbai, India

Mercury liquid- Prime dental products Pvt Ltd. Mumbai, India

2. Zinc phosphate cement-PyraxPolymars, Roorkee, India

3. Glass Ionomer Cement (GIC) - GC Corporation, Tokyo, Japan

4. Composite - Ivoclarvivadent marketing Pvt Ltd. Mumbai, India

Curing light - LED curing light, LEDition, Ivoclarvivadent marketing Pvt Ltd. Mumbai, India

The teeth used in the study were divided into following 3 groups:

- Group 1: 80 extracted teeth (20 intact teeth+ 60 teeth restored with different restorative materials of $20 \mathrm{each})+\mathrm{HCl}$ solution

- Group 2: 80 extracted teeth (20 intact teeth +60 teeth restored with different restorative materials of 20 each) $+\mathrm{HNO}_{3}$ solution

- Group 3: 80 extracted teeth (20 intact teeth+ 60 teeth restored with different restorative materials of 20 each) $+\mathrm{H}_{2} \mathrm{SO}_{4}$ solution

Out of 240 extracted teeth, cavity preparations were done on 180 teeth of which, a set of 60 were restored with different restorative materials namely amalgam (after zinc phosphate base application), GIC and composite. The teeth with and without restorations from Group 1, Group 2 and Group 3 were immersed separately in 3 different acids in different containers. At intervals of 30 mins, 1 hr., 2 hrs., 4 hrs., 8 hrs., 15 hrs., 20 


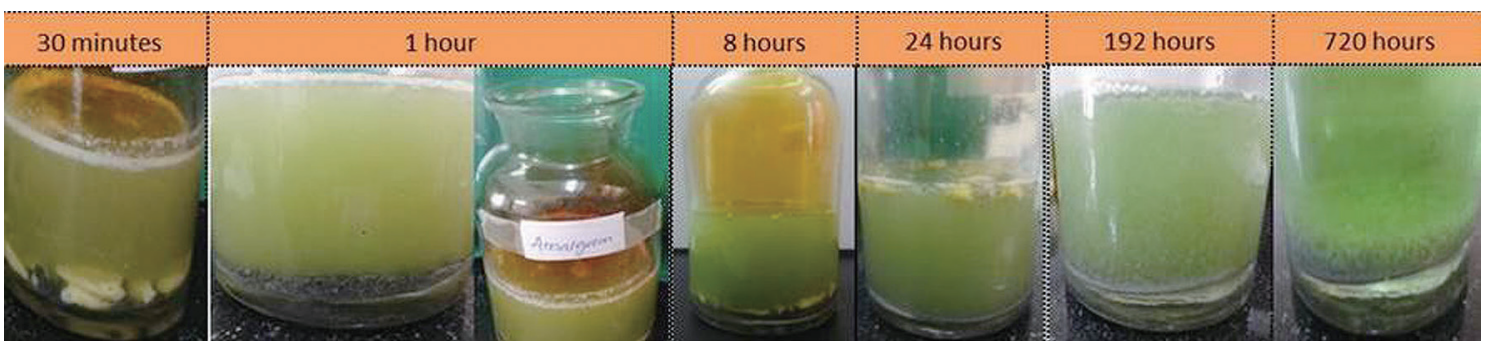

Figure 5. Sequential morphological changes observed in amalgam after immersion in nitric acid

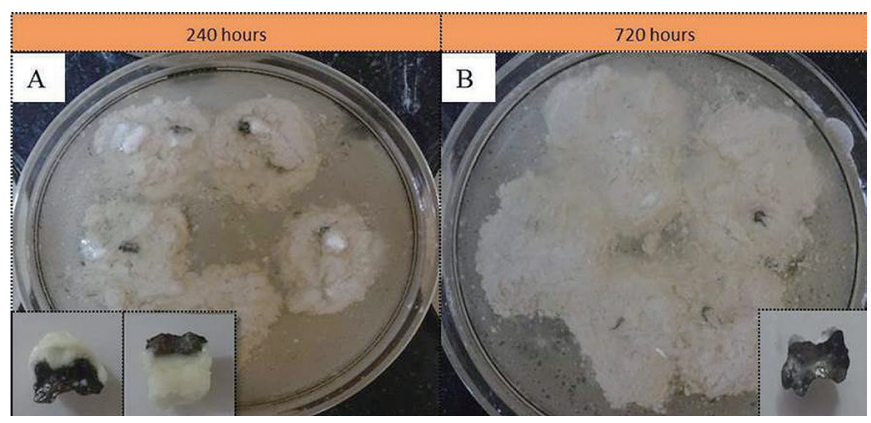

Figure 6. Sequential morphological changes observed in amalgam after immersion in sulphuric acid

hrs., 24 hrs., and thereafter for every 24 hrs until 30 days, the teeth and the restorations were examined for any morphological changes and photographed.

\section{Sample size calculation}

The sample size formula is given by:

$\mathrm{n}=\frac{\left\{Z_{1-\alpha / 2} \sqrt{P_{0}\left(1-P_{0}\right)}+Z_{1-\beta} \sqrt{P_{\mathrm{a}}\left(1-P_{\mathrm{a}}\right)}\right\}^{2}}{\left(P_{\mathrm{a}}-P_{0}\right)^{2}}$

Where,

$\mathrm{P}_{0}=$ Complete dissolution of teeth proportion $(0.5)$

$\mathrm{P}_{\mathrm{a}}=$ Duration proportion $(0.41)$

$\alpha=$ level of significance $(0.05)$

$1-\beta=$ Power of the study $(0.80)$

The time taken for the teeth to dissolve completely was 0.41 . The complete dissolution of all the teeth in all the acids was 0.5 . The level of significance was 0.05 and the power of the study was 0.8 .

On simplification, after applying the formula, the total number of teeth required for the present study was 240 (i.e, $\mathrm{n}=240$ ).

\section{Changes seen in teeth}

\section{Results}

\section{Morphological changes seen in teeth when placed in $\mathrm{HCl}$}

Effervescence was seen in acid solution after 30 mins. After $1 \mathrm{hr}$, the teeth were translucent only at the incisal edge or at the occlusal surface at $2 \mathrm{hrs}$ and this translucency progressively increased all around the teeth in the following hours of observation. Concentric circles appeared on the root at $4 \mathrm{hrs}$. After $8 \mathrm{hrs}$, teeth were gelatinous and eventually started floating in the acid solution. After $48 \mathrm{hrs}$ of immersion, all the teeth were completely dissolved, and the solution was clear (Fig. 1).

\section{Morphological changes seen in teeth when placed in $\mathrm{HNO}_{3}$}

Akin to $\mathrm{HCl}$, there was effervescence observed in $\mathrm{HNO}_{3}$ at 30 mins.

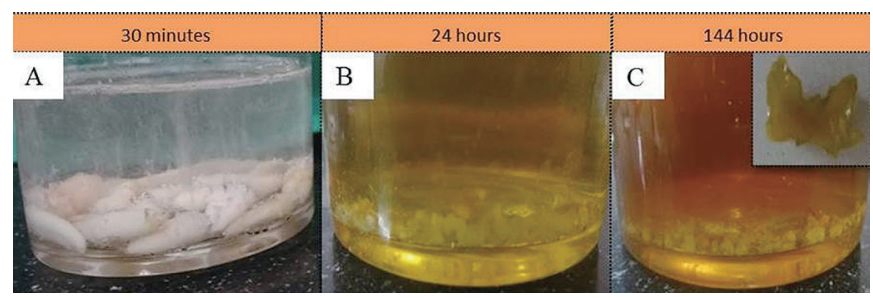

Figure 7. Sequential morphological changes observed in composite after immersion in hydrochloric acid

After $1 \mathrm{hr}$, the teeth were translucent only at the incisal edge/occlusal aspect and this translucency progressively increased all around the teeth in the following hours of observation. At this point, the teeth in $\mathrm{HCl}$ and $\mathrm{HNO}_{3}$ showed similar morphological changes, but the teeth in $\mathrm{HNO}_{3}$ were yellow in color which is helpful in differentiating which acid has been used. After $2 \mathrm{hrs}$, vertical fissure developed starting from incisal edge to the cervical third of the crown, which eventually deepened into a split extending towards the pulp by $2 \mathrm{hrs}$ and there was marked reduction in the tooth structure as well. Teeth became gelatinous at $8 \mathrm{hrs}$ and were completely dissolved by $20 \mathrm{hrs}$ (Fig. 2).

\section{Morphological changes seen in teeth when placed in $\mathrm{H}_{2} \mathrm{SO}_{4}$}

There were no morphological changes observed until $8 \mathrm{hrs}$, later precipitation on the teeth was noticed. In the following hours of observation, the precipitation on the teeth increased relatively and there was deposition of this precipitate at the bottom of the container as well. As the precipitate increased, there was reduction in the size of the teeth. After $72 \mathrm{hrs}$ of observation there was fragmentation of the teeth. Finally, the teeth were not recognizable and only precipitate was remaining at 288 hrs (Fig. 3).

The teeth that were restored with different restorative materials showed the same sequential changes as described above, irrespective of the type of restorations used to restore it. The only difference that was noted in case of teeth with restorations was that, there were delayed appearances of the morphological changes from the time that have been mentioned above.

\section{Changes seen in restorations}

\section{AMALGAM}

\section{Morphological changes seen in amalgam when placed in $\mathrm{HCl}$}

After $1 \mathrm{hr}$, the restorations started to dislodge from the teeth and only $50 \%$ of the teeth showed intact restorations in them. As the time progressed, at each time interval during the experiment, the restorations eventually dislodged, and all the teeth were completely devoid of restorations by $15 \mathrm{hrs}$. The zinc phosphate cement applied as base was not appreciated after the restorations were dislodged. The amalgam restorations whether intact or dislodged did not show any morphological 


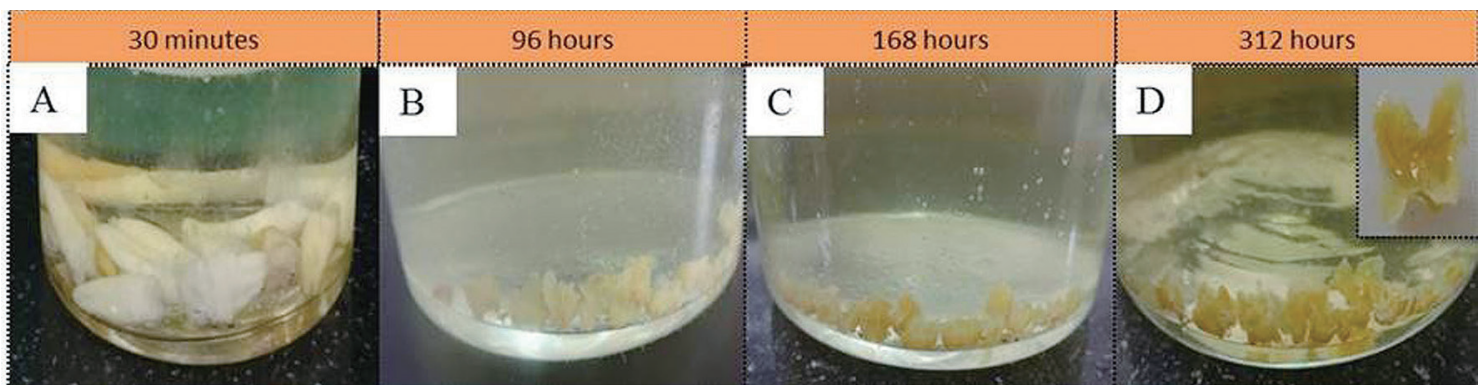

Figure 8. Sequential morphological changes observed in composite after immersion in nitric acid
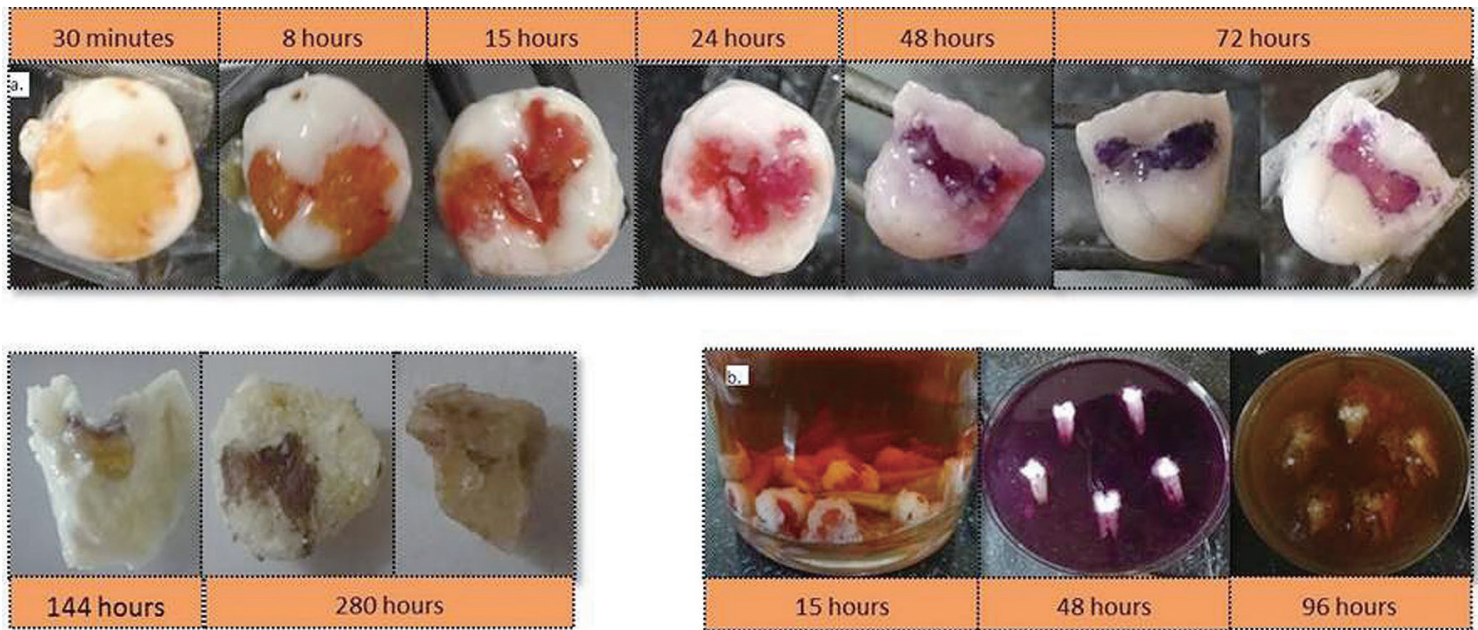

Figure 9. Sequential morphological changes observed in composite after immersion in sulphuric acid

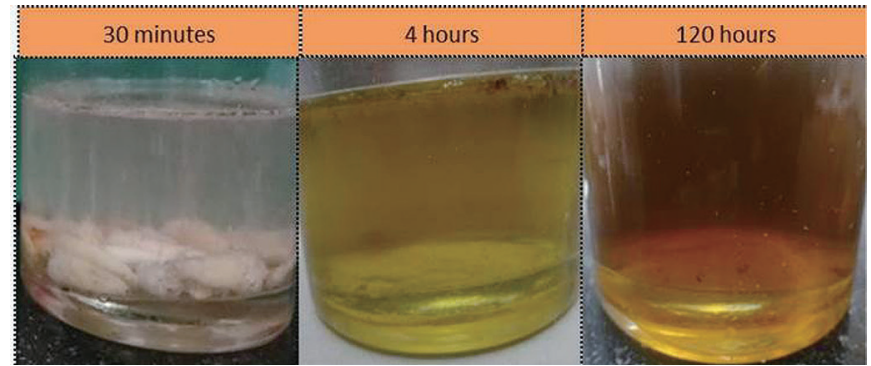

Figure 10. Sequential morphological changes observed in GIC after immersion in hydrochloric acid

changes throughout the observation period of 30 days and was in the same size and shape as it was during the commencement of the experiment (Fig. 4).

\section{Morphological changes seen in amalgam when placed in $\mathrm{HNO}_{3}$}

Bizarre changes were noted with respect to amalgam restorations. As soon as the teeth restored with amalgam were placed in $\mathrm{HNO}_{3}$, they got dislodged, in due course of time transformed into granules and settled at the bottom of the jar. The acid solution turned green. Another interesting finding that was noted at 30 mins was the emission of brown fumes probably because of the reaction between the acid and the amalgam restoration. As the time progressed, there was reduction in the amount of brown fumes emitted and completely disappeared by $28 \mathrm{hrs}$. At $192 \mathrm{hrs}$, the solution appeared slightly turbid. There were no further changes except for the fact that the solution was no longer turbid after $288 \mathrm{hrs}$. The granules at the bottom of the jar were not dissolved even after $720 \mathrm{hrs}$
(Fig. 5).

Morphological changes seen in amalgam when placed in $\mathrm{H}_{2} \mathrm{SO}_{4}$

Restorations started to dislodge from the teeth at $120 \mathrm{hrs}$. The dislodgement progressed slowly throughout the observation period and all the teeth were devoid of restorations by $360 \mathrm{hrs}$. Amalgam when placed in $\mathrm{H}_{2} \mathrm{SO}_{4}$ did not show any changes except for the surface of the restoration turning black which was noted at $240 \mathrm{hrs}$ (Fig. 6A). There were no other morphological changes appreciated and were in the same size and shape as it was during the commencement of the experiment (Fig. 6B).

\section{COMPOSITE}

\section{Morphological changes seen in composite when placed in $\mathrm{HCl}$}

The composite restorations started to dislodge from the teeth at $2 \mathrm{hrs}$ with eventual dislodgement on hourly basis and all the teeth were completely devoid of restorations by $24 \mathrm{hrs}$ (Fig. 7B). There were no considerable morphological changes appreciated in the composite restorations except for color change. The restorations were slightly brown at $144 \mathrm{hrs}$ (Fig. 7C) and the color intensified eventually until the last day of observation (i.e $720 \mathrm{hrs} / 30$ days) without any dissolution.

\section{Morphological changes seen in composite when placed in $\mathrm{HNO}_{3}$}

$25 \%$ of the restorations got dislodged at $1 \mathrm{hr}$. The restorations were getting dislodged eventually as the time progressed and all the teeth were completely devoid of restorations by $28 \mathrm{hrs}$. The restorations appeared slightly brown in color at 96 hrs (Fig. 8B). There was progressive increase in brown color up to $312 \mathrm{hrs}$ (Fig. 8C and D). At $312 \mathrm{hrs,}$ the restorations at the periphery became translucent because of which 
Thanuja Seethapathy et al.: Effect of Acids on Teeth and Restorative Materials

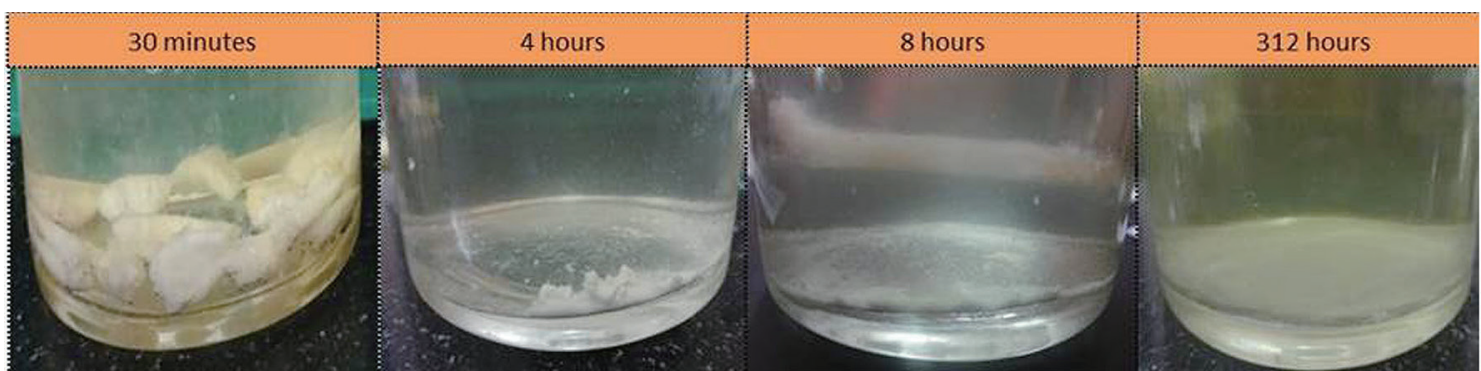

Figure 11. Sequential morphological changes observed in GIC after immersion in nitric acid

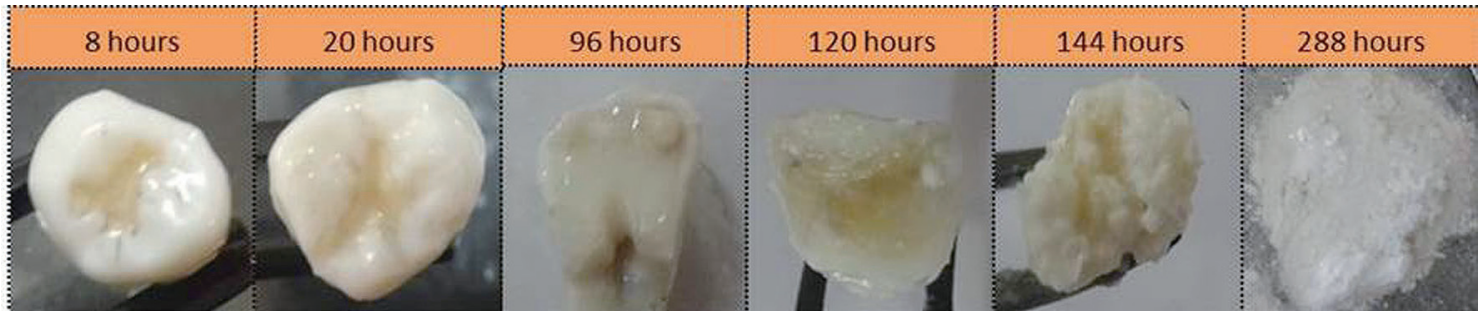

Figure 12. Sequential morphological changes observed in GIC after immersion in sulphuric acid

they appeared slightly smaller (Fig. 8D inset). No further morphological changes were observed at $720 \mathrm{hrs}$. As the changes seen in composite when placed in $\mathrm{HCl}$ and $\mathrm{HNO}_{3}$ are quite similar except for peripheral translucency, it is very difficult to identify which acid has been used and therefore further biochemical analysis has to be performed to recognize the acid.

\section{Morphological changes seen in composite when placed in $\mathrm{H}_{2} \mathrm{SO}_{4}$}

Unlike the changes seen so far in different restorations when placed in different acids, there were many changes noticed in composite restorations when placed in contact with $\mathrm{H}_{2} \mathrm{SO}_{4}$. The changes started to appear at 30 mins, where the restorations turned slightly yellow in color. At $8 \mathrm{hrs}$, the restorations changed their color from yellow to yellowish red. There were changes in color on the surface of the restorations from time to time, from being red to pink, later into brown (Fig. 9A).

At $15 \mathrm{hrs}$, the surface of the restorations appeared soft and eventually the softened surface got dissolved in the acid. The subsurface restoration (below the softened surface) that was not exposed to the acid was still hard in consistency and intact. The restorations started to dislodge from the teeth at $48 \mathrm{hrs}$ and this process of dislodgement continued slowly. By $384 \mathrm{hrs}$, all the teeth were completely devoid of restorations.

The restorations, both intact or dislodged, showed similar changes that were mentioned at $15 \mathrm{hrs}$, i.e the surface becoming soft and getting dissolved, and later the subsurface restoration gets exposed to acid becoming soft and dissolves eventually. This process continued till the restorations were completely dissolved. Except for 11 restorations that were still present even at $720 \mathrm{hrs}$ but showed reduction in their size.

Not only the restorations, even the solution in which the restored teeth were placed also showed changes in terms of color from time to time. First the solution was red in color at $8 \mathrm{hrs}$, and then turned into a darker shade of red at $15 \mathrm{hrs}$. Later, at $48 \mathrm{hrs}$ the solution turned pink and finally into brown color by $96 \mathrm{hrs}$ and henceforth till $720 \mathrm{hrs}$ (Fig. 9B).

\section{GIC}

Morphological changes seen in GIC when placed in $\mathrm{HCl}$

After $1 \mathrm{hr}$ of immersion of the teeth restored with GIC, half of the teeth $(50 \%)$ showed dislodged restorations. There was complete dislodgement of GIC from the teeth by $4 \mathrm{hrs,} \mathrm{which} \mathrm{was} \mathrm{quite} \mathrm{fast} \mathrm{when}$ compared to the time taken for the remaining 2 types of restorative materials to dislodge. The GIC, unlike the remaining restorations was collected as powder at the bottom of the jar. At $8 \mathrm{hrs}$, approximately half the amount of powder content got dissolved and the solution was clear with no evidence of powder by $120 \mathrm{hrs}$ (Fig. 10).

\section{Morphological changes seen in GIC when placed in $\mathrm{HNO}_{3}$}

Almost $50 \%$ of the teeth showed dislodgement of the restorations at $1 \mathrm{hr}$. By $2 \mathrm{hrs}$, except for one tooth, all the teeth were devoid of restorations. There was complete dislodgement of GIC from all the teeth by 4 hrs, which was quite fast when compared to the time taken for the remaining 2 types of restorative materials to dislodge. The GIC, unlike the remaining restorations was collected as powder at the bottom of the jar. At $8 \mathrm{hrs}$, the powder content was slightly reduced. As the time progressed, the powder got dissolved eventually and the solution was clear with no evidence of powder by $312 \mathrm{hrs}$. As the changes seen in GIC when placed in $\mathrm{HCl}$ and $\mathrm{HNO}_{3}$ are similar, it is difficult to identify which acid has been used and therefore further biochemical analysis has to be performed to recognize the acid (Fig. 11).

\section{Morphological changes seen in GIC when placed in $\mathrm{H}_{2} \mathrm{SO}_{4}$}

The restorations took longer time to dislodge when compared to those placed in $\mathrm{HCl}$ or $\mathrm{HNO}_{3}$. Restorations started to dislodge from the teeth at $120 \mathrm{hrs}$ and the dislodged restorations were brittle in nature. At $144 \mathrm{hrs}, 65 \%$ of the teeth showed intact restorations. At this hour, even the intact restorations became brittle. All the teeth were completely devoid of restorations by $288 \mathrm{hrs}$. As and when the restorations were dislodged, they became brittle and were easily manipulated with the slightest amount of pressure and transformed into powder which was indistinguishable from the white precipitate formed by the teeth at 288 hrs. Therefore, it was assumed to have been completely dissolved (Fig. 12).

Table 1 explains the sequential morphological changes seen in teeth and different restorative materials at various time intervals when placed in 3 different acids. 
J.Hard Tissue Biology Vol. 28(1): 21-30, 2019

Table 1. Morphological changes observed in teeth and different restorative materials when placed in 3 different acids

\begin{tabular}{|c|c|c|c|c|c|}
\hline \multicolumn{6}{|c|}{ HYDROCHLORIC ACID } \\
\hline DURATION & TEETH & $\begin{array}{c}\text { TEETH WITH } \\
\text { RESTORATIONS }\end{array}$ & AMALGAM & COMPOSITE & GIC \\
\hline 30 mins & Effervescence $(20 / 20)$ & Effervescence $(60 / 60)$ & No change & No change & No change \\
\hline $1 \mathrm{hr}$ & $\begin{array}{l}\text { Translucency started to } \\
\text { appear }(20 / 20)\end{array}$ & $\begin{array}{l}\text { Minimal reduction in the } \\
\text { size of the teeth were noted }\end{array}$ & $\begin{array}{l}\text { Dislodged restorations } \\
(10 / 20)\end{array}$ & No change & $\begin{array}{l}\text { Dislodged restorations } \\
(10 / 20)\end{array}$ \\
\hline $2 \mathrm{hrs}$ & $\begin{array}{l}\text { Translucency all around the } \\
\text { teeth }\end{array}$ & No change & Dislodged (16/20) & Dislodged (3/20) & Dislodged (17/20) \\
\hline $4 \mathrm{hrs}$ & $\begin{array}{l}\text { Concentric circles started } \\
\text { to appear }\end{array}$ & $\begin{array}{l}\text { Translucency started to } \\
\text { appear }\end{array}$ & Dislodged (18/20) & Dislodged (10/20) & $\begin{array}{l}\text { All the teeth were devoid } \\
\text { of restoration }\end{array}$ \\
\hline $8 \mathrm{hrs}$ & $\begin{array}{l}\text { Teeth started to become } \\
\text { gelatinous }\end{array}$ & $\begin{array}{l}\text { Concentric circles started } \\
\text { to appear }\end{array}$ & Dislodged (19/20) & Dislodged (14/20) & $\begin{array}{l}\text { After getting dislodged, the } \\
\text { restoration turned into } \\
\text { powder, } 50 \% \text { of which got } \\
\text { dissolved. }\end{array}$ \\
\hline $15 \mathrm{hrs}$ & $\begin{array}{l}\text { Few teeth started to } \\
\text { fragment (anteriors), } \\
\text { posteriors became gelati- } \\
\text { nous }\end{array}$ & $\begin{array}{l}\text { Translucency all around the } \\
\text { teeth }\end{array}$ & $\begin{array}{l}\text { All the teeth were devoid } \\
\text { of restorations }\end{array}$ & Dislodged (16/20) & $\begin{array}{l}\text { Further dissolution of the } \\
\text { powder content }\end{array}$ \\
\hline $20 \mathrm{hrs}$ & $\begin{array}{l}\text { Anteriors- near complete } \\
\text { dissolution, posteriors } \\
\text { - fragmentation }\end{array}$ & $\begin{array}{l}\text { Fragmentation of } 1 \text { or } 2 \\
\text { teeth. No other changes }\end{array}$ & $\begin{array}{l}\text { The dislodged restorations } \\
\text { did not show any changes. } \\
\text { Were in the same size and } \\
\text { shape }\end{array}$ & Dislodged (18/20) & No change \\
\hline $24 \mathrm{hrs}$ & $\begin{array}{l}\text { Anteriors- completely } \\
\text { dissolved }\end{array}$ & $\begin{array}{l}\text { Teeth started to become } \\
\text { gelatinous. Fragmentation- } \\
5 / 60\end{array}$ & No change & $\begin{array}{l}\text { All the teeth were devoid } \\
\text { of restorations }\end{array}$ & No change \\
\hline $28 \mathrm{hrs}$ & No change & Fragmentation- 20/60 & No change & $\begin{array}{l}\text { No changes were observed } \\
\text { neither in shape nor in size }\end{array}$ & No change \\
\hline $36 \mathrm{hrs}$ & No change & $\begin{array}{l}\text { Nearly } 50 \text { teeth got } \\
\text { fragmented }\end{array}$ & - & - & - \\
\hline $48 \mathrm{hrs}$ & $\begin{array}{l}\text { Complete dissolution of all } \\
\text { the teeth }\end{array}$ & $\begin{array}{l}\text { Almost all the teeth showed } \\
\text { near complete dissolution } \\
\text { complete dissolution- } 5 / 60\end{array}$ & - & - & - \\
\hline $72 \mathrm{hrs}$ & & $\begin{array}{l}\text { Complete dissolution- } \\
36 / 60\end{array}$ & & & \\
\hline $96 \mathrm{hrs}$ & & $\begin{array}{l}\text { Complete dissolution- } \\
54 / 60\end{array}$ & & & \\
\hline $108 \mathrm{hrs}$ & & $\begin{array}{l}\text { Complete dissolution of all } \\
\text { the teeth }\end{array}$ & & & \\
\hline $120 \mathrm{hrs}$ & & & & & $\begin{array}{l}\text { The solution was clear with } \\
\text { no evidence of any powder }\end{array}$ \\
\hline $144 \mathrm{hrs}$ & & & & $\begin{array}{l}\text { The restorations turned } \\
\text { slightly brown }\end{array}$ & \\
\hline \multicolumn{6}{|c|}{ NITRIC ACID } \\
\hline DURATION & ТЕЕТН & $\begin{array}{l}\text { TEETH WITH } \\
\text { RESTORATIONS }\end{array}$ & AMALGAM & COMPOSITE & GIC \\
\hline 30 mins & Effervescence (20/20) & Effervescence $(60 / 60)$ & $\begin{array}{l}\text { The solution turned green } \\
\text { with emission of brown } \\
\text { Fumes. } \\
\text { The restorations were } \\
\text { getting dislodged, de- } \\
\text { formed and were settling at } \\
\text { the bottom of the container }\end{array}$ & No change & No change \\
\hline $1 \mathrm{hr}$ & $\begin{array}{l}\text { Teeth started to become } \\
\text { translucent }\end{array}$ & $\begin{array}{l}\text { Minimal reduction in the } \\
\text { size of all the teeth were } \\
\text { noted }\end{array}$ & $\begin{array}{l}\text { All the teeth were devoid } \\
\text { of restorations }\end{array}$ & Dislodged $(5 / 20)$ & Dislodged (9/20) \\
\hline $2 \mathrm{hrs}$ & $\begin{array}{l}\text { Vertical split appeared in } \\
\text { few teeth }\end{array}$ & $\begin{array}{l}\text { Teeth started to become } \\
\text { translucent }\end{array}$ & No further changes & Dislodged (9/20) & Dislodged (19/20) \\
\hline $4 \mathrm{hrs}$ & $\begin{array}{l}\text { Reduction in the size of the } \\
\text { teeth }\end{array}$ & $\begin{array}{l}\text { Further reduction in size, } \\
\text { few of the teeth showed } \\
\text { concentric circles }\end{array}$ & $"$ & Dislodged (12/20) & $\begin{array}{l}\text { All the teeth were devoid } \\
\text { of restoration. The restora- } \\
\text { tions turned into powder } \\
\text { and settled at the bottom }\end{array}$ \\
\hline $8 \mathrm{hrs}$ & $\begin{array}{l}\text { Marked reduction in size } \\
\text { Fragmented - few teeth }\end{array}$ & Vertical split was noted & " & " & $\begin{array}{l}\text { Reduction in the powder } \\
\text { content }\end{array}$ \\
\hline $15 \mathrm{hrs}$ & $\begin{array}{l}\text { Near complete dissolution } \\
\text { of few teeth }\end{array}$ & $\begin{array}{l}\text { Marked reduction in the } \\
\text { teeth, they started to } \\
\text { become gelatinous }\end{array}$ & $"$ & Dislodged (17/20) & $"$ \\
\hline $20 \mathrm{hrs}$ & $\begin{array}{l}\text { Complete dissolution of all } \\
\text { the teeth }\end{array}$ & $\begin{array}{l}\text { Near complete dissolution- } \\
\text { few teeth } \\
\text { Fragmentation- few teeth }\end{array}$ & " & " & $\begin{array}{l}\text { The solution had some } \\
\text { powder }\end{array}$ \\
\hline $24 \mathrm{hrs}$ & & $\begin{array}{l}\text { Almost all the teeth were } \\
\text { fragmented with near } \\
\text { complete dissolution }\end{array}$ & $\begin{array}{l}\text { Solution- green } \\
\text { Reduction in the amount of } \\
\text { brown Fumes released }\end{array}$ & Dislodged (18/20) & $"$ \\
\hline
\end{tabular}


Thanuja Seethapathy et al.: Effect of Acids on Teeth and Restorative Materials

\begin{tabular}{|c|c|c|c|c|c|}
\hline $28 \mathrm{hrs}$ & & $\begin{array}{l}\text { Complete dissolution- } \\
10 / 60 \\
\text { Rest all near complete } \\
\text { dissolution }\end{array}$ & $\begin{array}{l}\text { Solution- green } \\
\text { No brown Fumes were } \\
\text { released }\end{array}$ & $\begin{array}{l}\text { All the teeth were devoid } \\
\text { of restoration, restorations } \\
\text { were slightly brown in } \\
\text { colour }\end{array}$ & $"$ \\
\hline $48 \mathrm{hrs}$ & & $\begin{array}{l}\text { Complete dissolution- } \\
31 / 60\end{array}$ & $"$ & No change & " \\
\hline $72 \mathrm{hrs}$ & & $\begin{array}{l}\text { Complete dissolution- } \\
57 / 60\end{array}$ & $"$ & $"$ & $"$ \\
\hline $96 \mathrm{hrs}$ & & $\begin{array}{l}\text { All the teeth were com- } \\
\text { pletely dissolved }\end{array}$ & & & \\
\hline $120 \mathrm{hrs}$ & & & & & $\begin{array}{l}\text { The solution was almost } \\
\text { clear with the powder } \\
\text { hardly evident }\end{array}$ \\
\hline $192 \mathrm{hrs}$ & & & $\begin{array}{l}\text { Slight turbidity was noted } \\
\text { in the solution }\end{array}$ & & \\
\hline $312 \mathrm{hrs}$ & & & & $\begin{array}{l}\text { The periphery of the } \\
\text { restoration turned slightly } \\
\text { white }\end{array}$ & Completely dissolved \\
\hline \multicolumn{6}{|c|}{ SULPHURIC ACID } \\
\hline DURATION & TEETH & $\begin{array}{c}\text { TEETH WITH RESTO- } \\
\text { RATIONS }\end{array}$ & AMALGAM & COMPOSITE & GIC \\
\hline 30 mins & No change & No change & No change & Turned Yellow & No change \\
\hline $8 \mathrm{hrs}$ & $\begin{array}{l}\text { White precipitate appeared } \\
\text { on the crown and the roots } \\
\text { were comparatively darker }\end{array}$ & $\begin{array}{l}\text { White precipitate appeared } \\
\text { on the crown and the roots } \\
\text { were comparatively darker }\end{array}$ & $"$ & $\begin{array}{l}\text { Restorations- yellowish } \\
\text { red, Solution - red }\end{array}$ & $"$ \\
\hline $15 \mathrm{hrs}$ & $\begin{array}{l}\text { White precipitate appeared } \\
\text { even on the root, deposition } \\
\text { of the ppt at the bottom of } \\
\text { the container }\end{array}$ & $\begin{array}{l}\text { White precipitate appeared } \\
\text { even on the root, deposition } \\
\text { of the ppt at the bottom of } \\
\text { the container }\end{array}$ & $"$ & $\begin{array}{l}\text { Restorations turned Red } \\
\text { and soft on the surface, rest } \\
\text { of it was still hard and } \\
\text { intact }\end{array}$ & " \\
\hline $20 \mathrm{hrs}$ & $\begin{array}{l}\text { Uniform increase in the } \\
\text { precipitate on the teeth }\end{array}$ & $\begin{array}{l}\text { Uniform increase in the } \\
\text { precipitate on the teeth }\end{array}$ & $"$ & " & $"$ \\
\hline $24 \mathrm{hrs}$ & $\begin{array}{l}\text { Progressive increase in the } \\
\text { deposition of the precipi- } \\
\text { tate on the teeth as well as } \\
\text { in the solution }\end{array}$ & $\begin{array}{l}\text { Progressive increase in the } \\
\text { deposition of the precipi- } \\
\text { tate on the teeth as well as } \\
\text { in the solution }\end{array}$ & $"$ & $\begin{array}{l}\text { Colour of the restoration on } \\
\text { the surface turned Dark } \\
\text { Red from pink }\end{array}$ & $"$ \\
\hline $48 \mathrm{hrs}$ & $\begin{array}{l}\text { White precipitate deposi- } \\
\text { tion }\end{array}$ & Fragmented $-10 / 60$ & $"$ & $\begin{array}{l}\text { Dislodged }-1 / 20 \text {, Restora- } \\
\text { tions of solution were Pink } \\
\text { in color }\end{array}$ & $"$ \\
\hline $72 \mathrm{hrs}$ & Fragmented $-1 / 20$ & Fragmented $-32 / 60$ & $"$ & " & " \\
\hline $96 \mathrm{hrs}$ & Fragmented $-2 / 20$ & Fragmented $-40 / 60$ & $"$ & Solution turned brown & $"$ \\
\hline $120 \mathrm{hrs}$ & Fragmented $-6 / 20$ & $\begin{array}{l}\text { Fragmented }-43 / 60 \\
\text { Unidentifiable- } 24 / 60\end{array}$ & Dislodged - 4/20 & Dislodged $-2 / 20$ & $\begin{array}{l}\text { Dislodged }-5 / 20 \\
\text { The dislodged restoration } \\
\text { were brittle and can be } \\
\text { easily crushed, those that } \\
\text { were intact were still hard }\end{array}$ \\
\hline $144 \mathrm{hrs}$ & $\begin{array}{l}\text { Increase in the precipitate } \\
\text { deposition with further } \\
\text { reduction in the teeth size }\end{array}$ & $\begin{array}{l}\text { Increase in the precipitate } \\
\text { deposition with further } \\
\text { reduction in the teeth size. } \\
\text { Fragmented }-48 / 60 \\
\text { Unidentifiable }-35 / 60\end{array}$ & No change & Dislodged - 4/20 & Dislodged $-7 / 20$ \\
\hline $168 \mathrm{hrs}$ & & $\begin{array}{l}\text { Fragmented }-53 / 60 \\
\text { Unidentifiable }-45 / 60\end{array}$ & Dislodged - 5/20 & Dislodged - 8/20 & Dislodged $-15 / 20$ \\
\hline $192 \mathrm{hrs}$ & & $\begin{array}{l}\text { Fragmented }-56 / 60 \\
\text { Unidentifiable }-50 / 60\end{array}$ & Dislodged $-7 / 20$ & $\begin{array}{l}\text { Dislodged - 12/20 } \\
\text { Restorations- brown }\end{array}$ & $\begin{array}{l}\text { The dislodged restoration } \\
\text { could not be differentiated } \\
\text { from the white precipitate } \\
\text { of teeth }\end{array}$ \\
\hline $216 \mathrm{hrs}$ & & $\begin{array}{l}\text { Fragmented }-56 / 60 \\
\text { Unidentifiable }-53 / 60\end{array}$ & Dislodged $-8 / 20$ & Dislodged - 12/20 & Dislodged - 19/20 \\
\hline $240 \mathrm{hrs}$ & & $\begin{array}{l}\text { Fragmented }-59 / 60 \\
\text { Unidentifiable }-56 / 60\end{array}$ & Dislodged - 15/20 & Dislodged - 13/20 & Dislodged - 19/20 \\
\hline $288 \mathrm{hrs}$ & & $\begin{array}{l}\text { All the teeth were frag- } \\
\text { mented and unidentifiable }\end{array}$ & Dislodged - 17/20 & Dislodged - 14/20 & $\begin{array}{l}\text { Dislodged }-20 / 20 \\
\text { Restorations if any were } \\
\text { not distinguishable from } \\
\text { the white precipitate of } \\
\text { teeth }\end{array}$ \\
\hline $312 \mathrm{hrs}$ & & $\begin{array}{l}\text { Reduction in teeth size } \\
\text { Increase in white precipi- } \\
\text { tate }\end{array}$ & Dislodged - 18/20 & Dislodged - 15/20 & $"$ \\
\hline $360 \mathrm{hrs}$ & & " & $\begin{array}{l}\text { All the restoration were } \\
\text { dislodged from the teeth }\end{array}$ & $"$ & $"$ \\
\hline
\end{tabular}




\section{Discussion}

Identification of humans using the unique features of teeth and jaws has been used since Roman times ${ }^{13,14}$. Human being has come a long way from the early caveman age to the present day of covering nothing less than astronomical heights to sea bed depths. His zeal to conquer new heights has created a world full of scientific advancement and technology. However, his intelligence has also led to a surge in crime rate, terrorism, wars, mass disasters, road traffic accidents and dreadful diseases. In all such incidents the identity of the deceased, assailant or the cause of death becomes important as the core of various investigations are based on the mode of crime ${ }^{15,16)}$.

Practice of forensic sciences often involves person/victim identification. As methods in personnel identification have increased or improved, so have the attempts of perpetrators of crime in circumventing those methods. Destruction of evidence including dead bodies by the use of concentrated inorganic acids is one such attempt. This was not entirely a novel method and came out to the fore of public realm probably half a century ago ${ }^{17)}$.

There is a paradigm shift in the treatment protocol from extraction to restorative procedures. Hence the major agenda of every dentist in the present scenario is preservation of the tooth structure rather than extraction and subsequent replacement. Now-a-days, with increasing incidence of caries, wider population have their teeth restored with different restorative materials, hence there is a need not only to know the changes in the tooth structure when subjected to different concentrated acids, but also to know the changes in various restorative materials. Though teeth are considered hardest structures in the human body, they can at times get destroyed at unusual circumstances, in such cases when restorations are retrieved, they could serve as a useful tool in identifying an individual by approaching a step closer in solving the case in acid crimes.

Teeth react with acids in different ways and the chemical reaction between teeth and different acids are given below:

\section{Teeth in $\mathrm{HCl}$}

The calcium present in the teeth reacts with the acid to form completely soluble salt i.e $\mathrm{CaCl}_{2}$, which results in the complete dissolution of the teeth and the reaction is as follows:

$\mathrm{Ca}^{+2}+2 \mathrm{HCl} \longrightarrow \mathrm{CaCl}_{2}+\mathrm{H}_{2}$ (completely soluble salt) ${ }^{1,9)}$

\section{Teeth in $\mathrm{HNO}_{3}$}

The calcium present in the teeth reacts with $\mathrm{HNO}_{3}$ to form $\mathrm{Ca}\left(\mathrm{NO}_{3}\right)_{2}$, soluble salt. The following reaction takes place between the acid and the teeth:

$\mathrm{Ca}^{+2}+2 \mathrm{HNO}_{3} \longrightarrow \mathrm{Ca}\left(\mathrm{NO}_{3}\right)_{2}+\mathrm{H}_{2}$ (completely soluble salt) ${ }^{1,9)}$

The following chemical reaction possibly explains the color change that is seen in the teeth when placed in nitric acid:

$\mathrm{CaSO}_{4}+2 \mathrm{HNO}_{3} \longrightarrow \mathrm{Ca}\left(\mathrm{NO}_{3}\right)_{2}+\mathrm{H}_{2} \mathrm{SO}_{4}{ }^{1,9)}$

Calcium sulphate reacts with nitric acid and forms calcium nitrate and sulphuric acid. The $\mathrm{Ca}\left(\mathrm{NO}_{3}\right)_{2}$ is responsible for the yellowish deposit on the teeth ${ }^{1,9)}$.

\section{Teeth in $\mathrm{H}_{2} \mathrm{SO}_{4}$}

The teeth placed in $\mathrm{H}_{2} \mathrm{SO}_{4}$ solution behaved completely different when compared to those that were placed in $\mathrm{HCl}$ and $\mathrm{HNO}_{3}$ solutions, presumably because of the following reaction

$\mathrm{Ca}^{+2}+\mathrm{H}_{2} \mathrm{SO}_{4} \longrightarrow \mathrm{CaSO}_{4}$ (insoluble salt) ${ }^{1,9)}$

The calcium present in the teeth reacts with $\mathrm{H}_{2} \mathrm{SO}_{4}$ and formed an insoluble $\mathrm{CaSO}_{4}$ salt that got precipitated.
In the literature, to the best of the present knowledge no studies have been performed where the morphological changes in various restorative materials when placed in contact with different acids were done to compare. Except for a brief mention by Mazza et al., ${ }^{8}$ wherein, as an experimental note, it was mentioned that one sample showed a residual central structure not destroyed by the acid and was identified as guttapercha bulk. Later as a part of the experiment, they have sectioned the guttapercha into 2 fragments. One fragment was submerged in pure $\mathrm{HCl}$ and the other in $\mathrm{HNO}_{3}$. Following an observation period of $50 \mathrm{hrs}$, none of the fragments showed dissolution.

In conclusion, morphological changes in teeth and different restorative materials can help the forensic investigator to deduce the time elapsed since immersion of body in an acid. The present study could be of great help when it is no longer possible to identify dental structures that have been dissolved in acid, the restorative materials if retrieved in such a situation could serve as a useful tool in forensic investigations. Additionally, to compare the residuals of dissolution with the ante-mortem records would be an aid in dental human identification.

It may be possible to identify the acid used to destroy a body based on these morphological changes. However, biochemical analysis helps in recognizing the acid as a more dependable tool. Additional studies and further investigations that look into the effect of acids on other dental materials could develop useful data in such crimes.

\section{Conflict of Interest}

The authors declared that they have no conflict of interest.

\section{References}

1. Gupta J, Gupta KK, Kabiraj A, Samadi FM, Karki RS and Yadav S. Morphological analysis of extracted human teeth in 3 different acids as an aid in forensic identification. World J Pharm Res 4: 19821992, 2015

2. Saxena S, Sharma P and Gupta N. Experimental studies of forensic odontology to aid in the identification process. J Forensic Dent Sci 2: 69-76, 2010

3. Whittaker DK. Research in forensic odontology. Ann R Coll Surg Engl 64: 175-179, 1982

4. Lund $\mathrm{H}$ and Mörnstad H. Gender determination by odontometrics in a Swedish population. J Forensic Odontostomatol 17: 30-34, 1999

5. Dinakaran J, Dineshkumar T, Nandhini G, Priyadharshini N and Rajkumar K. Gender determination using dentition. SRM J Res Dent Sci 6: 29-34, 2015

6. Pretty IA and Sweet D. Forensic dentistry: A look at forensic dentistry-Part 1: The role of teeth in the determination of human identity. Br Dent J 190: 359-366, 2001

7. Eckert WG. Chapter 1. In: Introduction to the forensic sciences, ed by Eckert WG, CRC press, 1997, pp 1-10.

8. Mazza A, Merlati G,Savio C, Fassina G, Menghini P and Danesino P. Observations on dental structures when placed in contact with acids: Experimental studies to aid identification processes. J Forensic Sci 50: 406-410, 2005

9. Jadhav K, Gupta N, Mujib BA and Amberkar VS. Effect of acids on the teeth and its relevance in postmortem identification. J Forensic Dent Sci 1: 93-98, 2009

10. Cleland J. Teeth and bites in history and literature. Austr J Dent 48: 3, 1944

11. Holden R and Simpson CK. The acid bath murder(s). Police J 102: 23, 1950

12. Bruce-Chwatt RM. A brief history of Forensic odontology since 
Thanuja Seethapathy et al.: Effect of Acids on Teeth and Restorative Materials

1775. J Forensic Leg Med 17: 127-130, 2010

13. Sreedhar G, Sumalatha MN, Ramesh G, Nagarajappa R, Murari A and Agrawal A. Dimorphic Mandibular canines in gender determination in Moradabad population of western Uttar Pradesh. J Forensic Dent Sci 7: 32-36, 2015

14. Fixott RH. Forensic Odontology. WB Saunders Company, 2001, pp 224, 249, 253.

15. Shekar BC and Reddy CV. Role of dentist in person identification.
Indian J Dent Res 20: 356-360, 2009

16. Fixot RH. How to become involved in forensic odontology. Dent Clin North Am 45: 417-426, 2001

17. Sowmya K, Sudheendra US, Khan S, Nagpal N and Prathamesh SJ. Assessment of morphological changes and DNA quantification: An in vitro study on acid-immersed teeth. J Forensic Dent Sci 5: 42-46, 2013 
J.Hard Tissue Biology Vol. 28(1): 21-30, 2019 